\title{
Acute pancreatitis and macrophage activation syndrome in pediatric systemic lupus erythematosus: case-based review
}

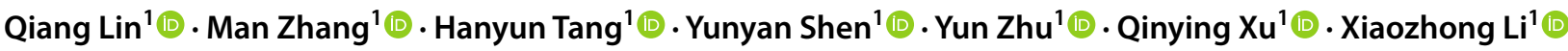

Received: 10 February 2019 / Accepted: 17 July 2019 / Published online: 3 August 2019

(c) The Author(s) 2019

\begin{abstract}
Pancreatitis is uncommon in systemic lupus erythematosus (SLE) and is rarely reported in children, possibly being related to macrophage activation syndrome (MAS). The incidence of MAS in children with lupus pancreatitis is unknown, as is their prognosis. In this case-based review, we report a pediatric patient with SLE complicated with pancreatitis and MAS, and performed a literature review. We report an 11-year-old girl with SLE and MAS who developed pancreatitis on the second day of methylprednisolone pulse therapy $(500 \mathrm{mg} / \mathrm{day})$. We continued methylprednisolone pulse therapy, and performed three rounds of DNA-immunoadsorption and three rounds of hemoperfusion. A second course of methylprednisolone pulse therapy was initiated 9 days later. The patient received a monthly cyclophosphamide pulse therapy $(10 \mathrm{mg} / \mathrm{kg} / \mathrm{day}, 2$ consecutive days every month) for 6 months, after which she was treated with mycophenolate mofetil $20 \mathrm{mg} / \mathrm{kg} / \mathrm{day}$. The condition of the patient gradually improved, her blood amylase and lipase decreased. She was in a stable condition during 13-month follow-up period. Review of the literature of pediatric patients with SLE and pancreatitis showed that there are 127 cases that have been reported in the past 30 years, 40 cases were excluded in our study because of inadequate information. Of the 87 patients included in our literature review, the mortality rate was $33.33 \%$, and $52.86 \%$ of the patients with pancreatitis had MAS at the same time. Pancreatitis is uncommon in SLE, but must be suspected if a patient with SLE develops digestive symptoms. Patients with SLE with pancreatitis have a high incidence of MAS and high mortality rate; however, early recognition and effective treatment can relieve the disease symptoms.
\end{abstract}

Keywords Pancreatitis $\cdot$ Lupus erythematosus, systemic $\cdot$ Macrophage activation syndrome $\cdot$ Pediatrics $\cdot$ Case reports

\section{Introduction}

Systemic lupus erythematosus (SLE) is an autoimmune disease with various clinical presentations, and virtually every organ and system can be affected. Gastrointestinal

Qiang Lin and Man Zhang contributed equally to this work and share the first authorship.
Xiaozhong $\mathrm{Li}$
xiaozhonglicn@yeah.net
Qiang Lin
wslinqiang@aliyun.com
Man Zhang
1193008857@qq.com
Hanyun Tang
tanghanyun90@126.com
Yunyan Shen
syunyan@sohu.com

symptoms are common in SLE patients, and the incidence of gastrointestinal involvement is 19\% in pediatric SLE and $8-40 \%$ in adult SLE [1]. Ascites is the most common in abdominal involvement, which occurs in $8-11 \%$ of adult patients with SLE [1]. Lupus-related pancreatitis in adults has been reported [2]. The pathogenic mechanism of lupusrelated pancreatitis is complex and multifactorial, and might be related to vasculitis and immune-mediated pancreatic

Yun Zhu

52946664@qq.com

Qinying Xu

listenway_li@163.com

Department of Nephrology and Immunology, Children's Hospital of Soochow University, 303, Jingde Road, Suzhou, Jiangsu, The People's Republic of China 
injury [2]. Acute pancreatitis is very rare in pediatric SLE populations, with most published studies being related to case reports. Some of these patients also suffered from macrophage activation syndrome (MAS) [3]. The number of pediatric patients with lupus pancreatitis is very small; therefore, the mortality and outcome of children with lupus pancreatitis are unknown. The incidence of MAS in pediatric lupus pancreatitis is also unknown.

In the present study, we report an 11-year-old girl with SLE and MAS who developed pancreatitis on the second day of methylprednisolone pulse therapy (500 $\mathrm{mg}$ per day for 3 days). The clinical presentation, laboratory profiles, and treatment are described. In presenting this case, along with other similar rare cases in the literature, our aim was to draw the attention of fellow rheumatologists to pancreatitis, which is a rare, but life-threatening, complication of SLE.

\section{Case presentation}

On January 30th, 2018, an 11-year-old girl was admitted to our hospital complaining of intermittent fever lasting for 3 weeks, with a maximum body temperature of $39^{\circ} \mathrm{C}$. The fever was accompanied by knee pain, fatigue, and a paroxysmal cough. She was intermittently treated with cephalosporins at a local hospital; however, the symptoms persisted. Her chest X-ray and bone marrow smear were normal. Blood tests in the local hospital showed leukopenia, thrombocytopenia and high serum ferritin (shown in Table 1). Her past history and family history were unremarkable. She was suspected of suffering from hemophagocytic lymphohistiocytosis and transferred to the hematology department of our hospital. On admission, she appeared sick, was febrile $\left(38.0{ }^{\circ} \mathrm{C}\right)$, and had a heart rate of 110 beats $/ \mathrm{min}$, a respiratory rate of 22 breaths/min, and her blood pressure was $120 / 85 \mathrm{mmHg}$. No abnormal findings were observed in her heart, lungs, and abdomen upon physical examination.

Lung infection was confirmed using chest computed tomography (CT). An abdominal CT showed no abnormality. Her Epstein-Barr virus (EBV)-DNA, cytomegalovirus (CMV)-DNA, Mycoplasma pneumoniae antibody, tuberculosis antibody, hepatitis B, hepatitis C, syphilis, HIV, and VB19-DNA tests were negative. She was treated with cefoperazone sulbactam for the lung infection.

The results of the laboratory tests are shown in Table 1.

After the results of the laboratory parameters were obtained, she was diagnosed as having SLE and MAS, and was transferred to our department: The Department of Nephrology and Immunology. Pulse therapy with methylprednisolone was administered (500 $\mathrm{mg}$ /day for 3 days). On the second day of pulse treatment, the patient developed abdominal pain and vomiting. A physical examination revealed abdominal tenderness and distention, and abdominal radiography indicated intestinal dilatation and incomplete intestinal obstruction. The patient received an intravenous injection of omeprazole and gastrointestinal decompression; however, her abdominal pain and distention did not improve, and she became lethargic. Abdominal CT demonstrated fluid accumulation surrounding the swollen pancreas. Amylase and lipase were tested immediately, the results confirms pancreatitis. Meropenem to treat the infection and parenteral nutrition support was initiated. Somatostatin was also administrated.

The treatment process is shown in Fig. 1.

Her abdominal pain gradually disappeared and her abdominal distension was relieved in 5-6 days. The laboratory parameters were gradually restored to normal. A kidney biopsy was performed, and most of the glomeruli showed mild to moderate mesangial hyperplasia. Four of the glomeruli had severe segmental mesangial hyperplasia, with a small amount of cellular necrosis and mild fibrosis being discovered in the tubulointerstitium. Oral prednisone $(2 \mathrm{mg} / \mathrm{kg} /$ day) was administered and then gradually reduced. The patient then received monthly cyclophosphamide pulse therapy $(10 \mathrm{mg} / \mathrm{kg} /$ day, 2 consecutive days every month) for 6 months. Her urine protein and hematuria became negative after 3 months. The patient was treated with mycophenolate mofetil $20 \mathrm{mg} / \mathrm{kg} /$ day after 6 months of cyclophosphamide pulse therapy. The patient remained in a stable condition after 13 months of follow-up.

\section{Search strategy}

A literature search for children with SLE and pancreatitis was carried out using various databases (Web of Science, Wiley Online Library, Elsevier Science Direct, and Pubmed) up to January 2019. The search was conducted using following key words: "lupus", "pancreatitis", and "child", "childhood", "children", "pediatric", "juvenile", and "adolescent". Studies reporting patients under 18 years old with lupus pancreatitis who were documented in the English language literature over the past 30 years (from 1988 to 2018) were examined.

\section{Literature review}

We identified 41 articles describing 127 patients in total [1-41].

Thirteen articles were excluded because of inadequate information [29-41]. Twelve papers reported 40 cases of lupus pancreatitis in children, 13 of whom died; however, details were not provided [29-40]. Another paper 
Table 1 Laboratory parameters of the patient with systemic lupus erythematosus and acute pancreatitis and macrophage activation syndrome

\begin{tabular}{|c|c|c|c|c|c|c|c|c|c|}
\hline $\begin{array}{l}\text { Laboratory } \\
\text { parameters }\end{array}$ & $\begin{array}{l}\text { One day } \\
\text { before } \\
\text { admission }\end{array}$ & $\begin{array}{l}\text { Day } 1 \text { (January } \\
\text { 30th. On admis- } \\
\text { sion) }\end{array}$ & $\begin{array}{l}\text { Day } 2 \text { (diagno- } \\
\text { sis of SLE and } \\
\text { MAS. Start of } \\
\text { MPT) }\end{array}$ & $\begin{array}{l}\text { Day } 3 \text { (detec- } \\
\text { tion of pancrea- } \\
\text { titis) }\end{array}$ & Day 5 & Day 7 & Day 15 & Day 34 & Normal range \\
\hline $\mathrm{WBC}\left(\times 10^{9} / \mathrm{L}\right)$ & 2.29 & 1.4 & - & - & 8.71 & 7.82 & 11.73 & 7.93 & $4-10$ \\
\hline $\begin{array}{l}\text { Neutrophils } \\
\left(\times 10^{9} / \mathrm{L}\right)\end{array}$ & 1.53 & 0.74 & - & - & 7.69 & 6.59 & 10.51 & 6.24 & $2-7.5$ \\
\hline $\begin{array}{l}\text { Lymphocytes } \\
\left(\times 10^{9} / \mathrm{L}\right)\end{array}$ & 0.57 & 0.46 & - & - & 0.6 & 0.57 & 0.66 & 1.16 & $0.8-4$ \\
\hline $\begin{array}{l}\text { Platelets } \\
\left.\qquad \times 10^{9} / \mathrm{L}\right)\end{array}$ & 78 & 56 & - & - & 63 & 56 & 114 & 374 & $100-300$ \\
\hline $\begin{array}{l}\text { Hemoglobin } \\
(\mathrm{g} / \mathrm{L})\end{array}$ & 96 & 90 & - & - & 97 & 71 & 80 & 98 & $110-140$ \\
\hline $\begin{array}{l}\text { Fibrinogen } \\
(g / L)\end{array}$ & - & 1.38 & - & - & 1.32 & 1.6 & 1.7 & - & $2-4$ \\
\hline $\begin{array}{l}\text { Serum albumin } \\
(\mathrm{g} / \mathrm{L})\end{array}$ & - & 27.6 & - & - & 27 & 29.8 & 26.8 & 39.1 & $38-54$ \\
\hline $\begin{array}{c}\text { Triglyceride } \\
(\mathrm{mmol} / \mathrm{L})\end{array}$ & - & 2.57 & - & - & 2.5 & 2.87 & 2.3 & 2.33 & $0-1.7$ \\
\hline ALT (U/L) & - & 374 & - & - & 185.7 & 135.9 & 89.4 & 53.7 & $5-35$ \\
\hline AST (U/L) & - & 995.8 & - & - & 620.3 & 521.1 & 259.5 & 54.3 & $10-67$ \\
\hline $\begin{array}{l}\text { Total bilirubin } \\
(\mu \mathrm{mol} / \mathrm{L})\end{array}$ & - & 42.5 & - & - & 73.56 & 108.98 & 78 & 18.87 & $3.4-17.1$ \\
\hline $\begin{array}{l}\text { Direct bilirubin } \\
(\mu \mathrm{mol} / \mathrm{L})\end{array}$ & - & 33.2 & - & - & 60.32 & 87.36 & 62.62 & 12.52 & $0-10$ \\
\hline $\begin{array}{l}\text { serum creati- } \\
\text { nine }(\mu \mathrm{mol} / \mathrm{L})\end{array}$ & - & 54.9 & - & - & 57.7 & 52.7 & 34.7 & 37.8 & $5-84$ \\
\hline Amylase (U/L) & - & - & - & 438.5 & - & 433.3 & 99 & 184 & $0-100$ \\
\hline Lipase (U/L) & - & 45.3 & - & 1113.1 & - & 814.9 & 145 & 72.2 & $13.0-63.0$ \\
\hline Ferritin (ng/mL) & 1364 & 2115 & - & - & 1852 & 1605 & 687 & 583 & $11.00-336.20$ \\
\hline Proteinuria & - & $50 \mathrm{mg} / \mathrm{dL}(+)$ & - & - & Negative & Negative & Negative & Negative & Negative \\
\hline Hematuria $(/ \mu \mathrm{L})$ & - & 52 & - & - & 314 & 268 & 61 & 28 & $0-22$ \\
\hline $\begin{array}{l}24 \mathrm{~h} \text { urine pro- } \\
\text { tein }(\mathrm{mg})\end{array}$ & - & 627 & - & - & - & - & - & - & $2-119$ \\
\hline ANA & - & $1: 1000$ & - & - & - & - & - & - & Negative \\
\hline $\begin{array}{l}\text { Anti-dsDNA } \\
\text { antibody }\end{array}$ & - & $1: 320$ & - & - & - & - & - & - & Negative \\
\hline $\begin{array}{l}\text { Soluble CD25 } \\
\text { (pg/mL) }\end{array}$ & - & 21127 & - & - & - & - & - & - & $<6400$ \\
\hline NK cell activity & - & $12.79 \%$ & - & - & - & - & - & - & $>15.11 \%$ \\
\hline $\operatorname{IgA}(\mathrm{g} / \mathrm{L})$ & - & 2.46 & - & - & - & - & - & 2.62 & $0.63-1.79$ \\
\hline $\operatorname{IgG}(\mathrm{g} / \mathrm{L})$ & - & 14.46 & - & - & - & - & - & 11.54 & $6.36-10.04$ \\
\hline $\operatorname{IgM}(\mathrm{g} / \mathrm{L})$ & - & 1.01 & - & - & - & - & - & 1.51 & $0.29-1.41$ \\
\hline C3 (g/L) & - & 0.16 & - & - & - & - & - & 0.75 & $0.79-1.52$ \\
\hline C4 (g/L) & - & 0.05 & - & - & - & - & - & 0.14 & $0.16-0.38$ \\
\hline
\end{tabular}

$W B C$ white blood cells, $A L T$ alanine aminotransferase, $A S T$ aspartate aminotransferase, ANA anti-nuclear antibody, dsDNA double-stranded DNA, NK cell natural killer cell, C3 complement component 3, C4 complement component 4, SLE systemic lupus erythematosus, MAS macrophage activation syndrome, $M P T$ methylprednisolone pulse therapy

reported 13 cases of childhood-onset SLE [41]; however, the number of patients with pancreatitis before the age of 18 years was not stated, and the study was from the same hospital as another report [37] and the time of the two articles overlapped. Thus, we could not exclude the possibility that patients were recruited repeatedly; therefore, this article was excluded. 


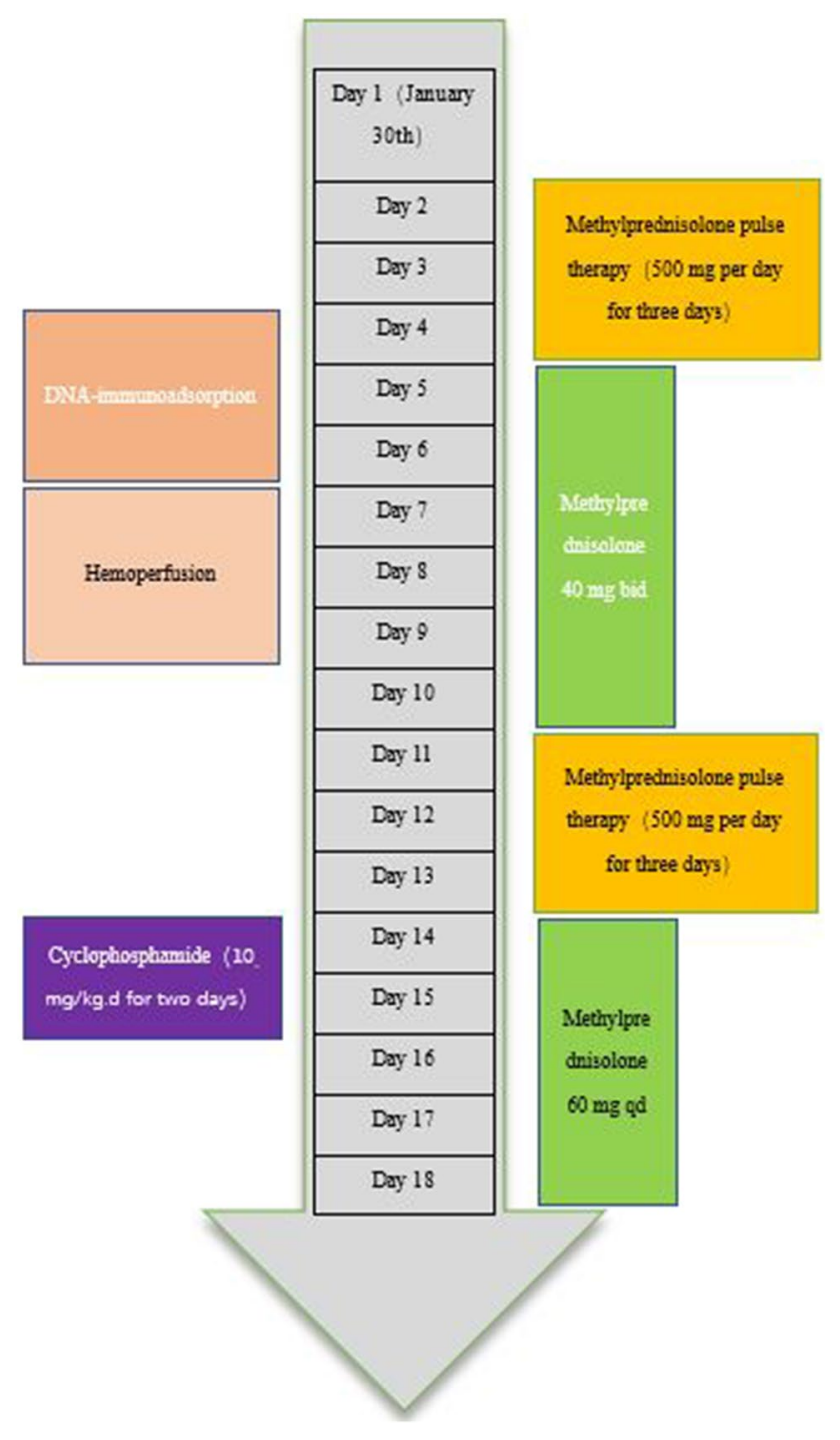

Fig. 1 Timeline of interventions in the pediatric systemic lupus erythematosus patient with pancreatitis and macrophage activation syndrome

Ultimately, 28 articles were included in our study, comprising 21 case reports and 7 original articles. Altogether 87 patients were analyzed [1-28].

Five pediatric patients were reported from 1988 to $1998 ; 18$ from 1999 to 2008 , and 64 from 2009 to 2018. In total, 29 patients died, giving a mortality rate of $33.33 \%$. It is not clear wether MAS existed in 17 patients because of inadequate descriptions, of the 70 children with adequate information, 37 could be diagnosed as having MAS, as shown in Table 2.

\section{Discussion}

Pancreatitis is rare in pediatric SLE patients, and there were only 127 pediatric patients reported in the past 30 years in English literature as far as we know. The past 30 years have witnessed an increase in the number of pediatric patients reported as having SLE with pancreatitis, more cases may be discovered in the future. Although it is rare, the mortality rate is high. Of the 87 patients included in our literature review, the mortality rate was $33.33 \%$, some survivors had pancreatic pseudocyst or diabetes mellitus. These findings are consistent with the literature [42].

$52.86 \%(37 / 70)$ of the patients with pancreatitis in our review had MAS at the same time, the frequency is much higher than those patients without pancreatitis, which is about 16-20\% [43]. The occurrence of pancreatitis and MAS in SLE may not be an accident. A study from Brazil showed that $85 \%$ of children with lupus pancreatitis suffered from concurrent MAS [19]. According to Campos et al., the pancreas may be a target organ of MAS in patients with SLE [3].

Gastrointestinal involvement in patients with SLE is a challenging from a diagnostic perspective, the symptoms include anorexia, nausea, vomiting, and abdominal pain [44]. These symptoms can be caused by many factors, some of these complications can be life threatening, such as perforation, intestinal infarction, and pancreatitis [42, 44].

The incidence of pancreatitis in adult patients with SLE varies from 0.7 to $4 \%$ [3]. There has been no large samplesized survey of the incidence of pancreatitis in children with SLE. A survey from France showed that pancreatitis is the second most common gastrointestinal symptom in SLE [1]; however, pancreatitis is rarely reported in children. An explanation might be as follows: Many patients with SLE with abdominal pain may be diagnosed as gastritis or other diseases; therefore, pancreatic enzymes do not get measured, and mild pancreatitis clears up by itself or is relieved by the corticosteroids administered to treat SLE [18]. Thus, the incidence of pancreatitis in SLE might be underestimated [18].

The diagnosis of pancreatitis in SLE is not difficult, and is mainly based on clinical symptoms, abdominal CT, and elevated serum levels of amylase or lipase. However, the etiology of pancreatitis is complex. Some scholars believe that pancreatitis in lupus may be related to the use of glucocorticoids [20]. Current oral glucocorticoid use may be associated with an increased risk of acute pancreatitis; the risk is highest at 4-14 days after drug dispensation and is attenuated thereafter [45]. Methylprednisolone pulse therapy may also be related to pancreatitis. At least nine cases of pancreatitis after methylprednisolone pulse 
Rheumatology International (2020) 40:811-819

815

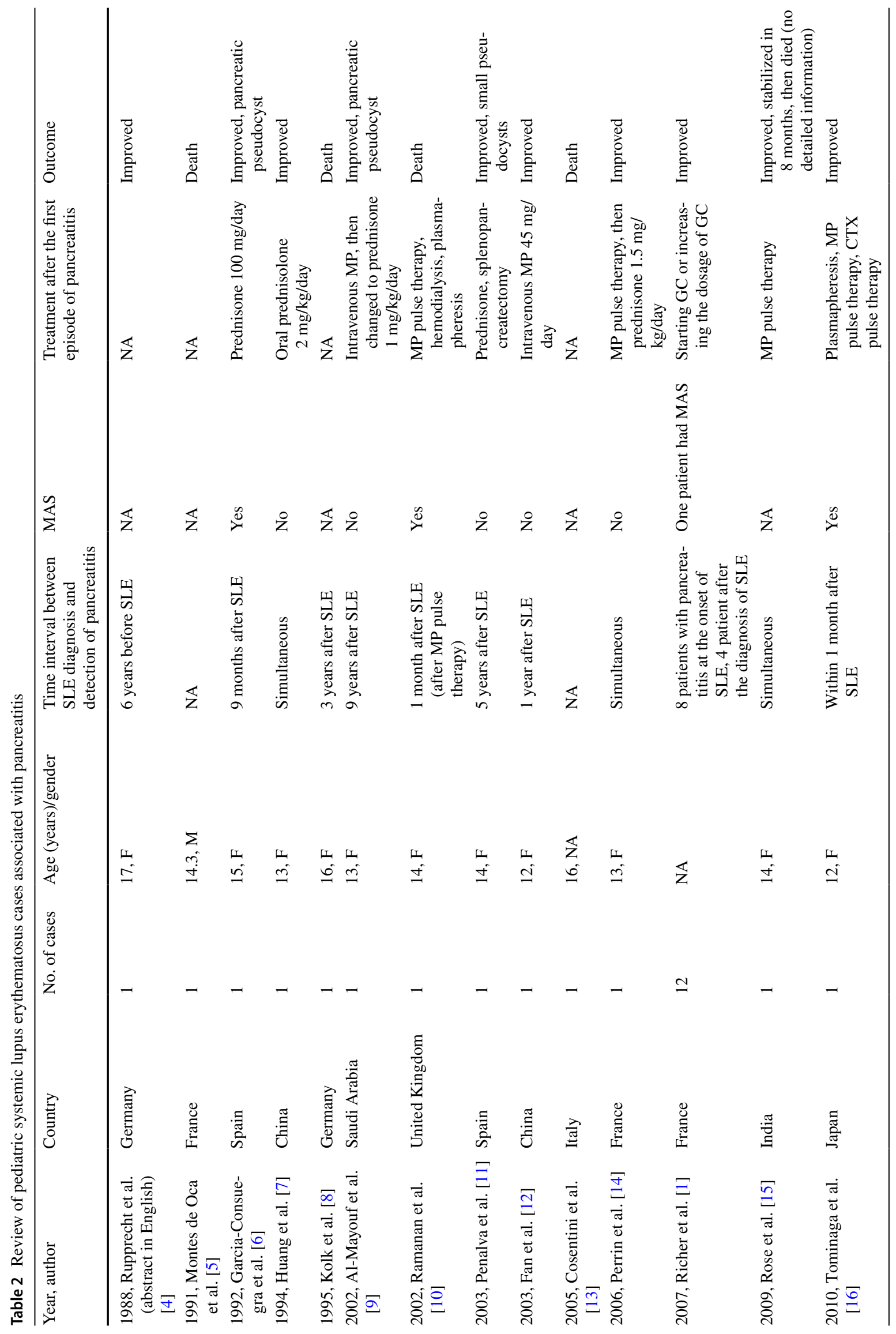

Springer 


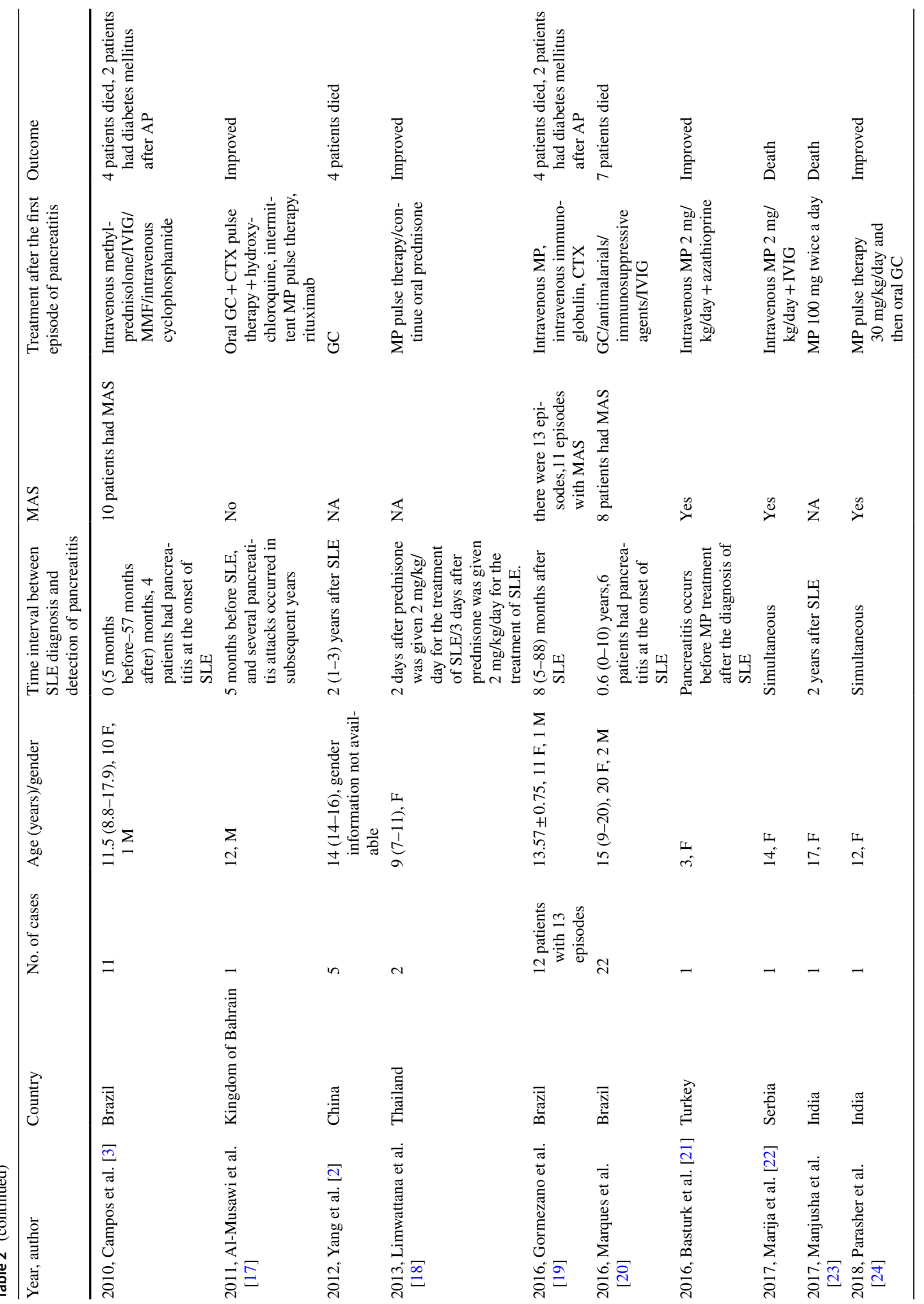




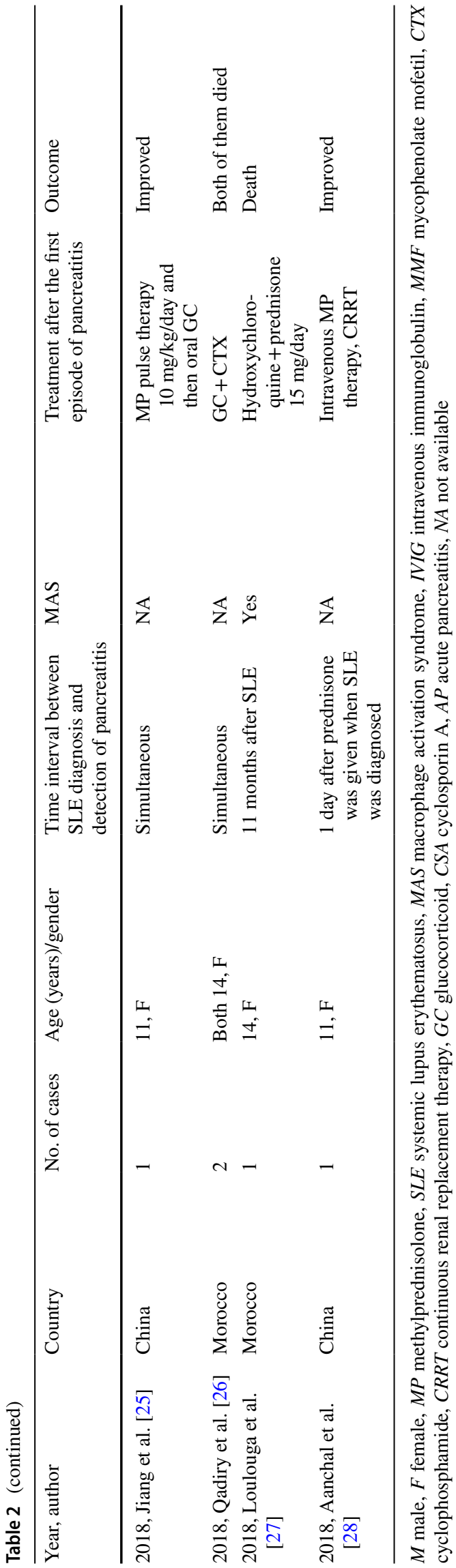

therapy have been reported, with a median latent period of 5 days [46]. However, only one pediatric patient with SLE who developed pancreatitis after methylprednisolone pulse therapy has been reported in the literature [10].

Our case developed pancreatitis on the second day of methylprednisolone pulse therapy; however, it was difficult to determine whether the pancreatitis was caused by the disease or by the glucocorticoids. We believe that in our case, the pancreatitis was possibly caused by lupus itself rather than glucocorticoids, for the following reasons: (1) some patients with SLE could develop pancreatitis before, or in the absence of, the use of corticosteroids [12, 18, 21]; (2) Patients with pancreatitis tend to achieve symptom resolution using continuous glucocorticoids or increasing the dose of glucocorticoids [1, 18]. (3) The occurrence of pancreatitis is related to the disease activity of lupus: the SLE disease activity index was significantly higher in patients with pancreatitis than in those without $[1,20]$; and (4) we started extracorporeal blood purification and continued methylprednisolone pulse therapy after our patient developed pancreatitis, and her condition gradually improved. A second course of methylprednisolone pulse therapy 9 days later did not induce pancreatitis. Increasing evidence suggests that the occurrence of pancreatitis in patients with SLE is not related to glucocorticoids. Among the patients who received intensive glucocorticosteroids, immunosuppressive agents, or both, $75 \%$ exhibited a favorable prognosis [2], indicating that these treatments could improve the survival rate of patients with SLE and pancreatitis [1,2].

As a method to rapidly and selectively eliminate autoantibodies and immune complexes in patients with SLE, DNAimmunoadsorption therapy can significantly reduce disease activity and protect organ function. For patients with severe SLE, immunosuppressive therapy combined with DNAimmunoadsorption may improve their prognosis, thereby saving their lives [47, 48]. Our patient was treated with DNA-immunoadsorption and glucocorticosteroid pulse therapy simultaneously, after which her clinical symptoms gradually eased. However, it was not possible to dissect the therapeutic effect of DNA-immunoadsorption from that of the corticosteroids.

The prognosis of lupus-related pancreatitis is not good, the mortality rate could be as high as $45 \%, 22 \%$ of patients with lupus-related pancreatitis may experience recurrent pancreatitis attacks, and $12 \%$ of patients develop pancreatic pseudocysts [42].

Although pancreatitis in SLE is rare, it could be life threatening, physicians should be suspicious of pediatric patients with SLE who present with gastrointestinal involvement. Pancreatitis and MAS often occur simultaneously in pediatric patients with SLE, and mortality is high. However, early recognition and effective treatment can relieve the disease symptoms. 
Author contributions QL/MZ: writing of initial draft of manuscript, editing and revision of manuscript at all stages of its production, review of the literature and management of the patient. HT/YS/YZ: contributed to editing of manuscript, review of the literature and management of the patient. QX: critically revised the manuscript, review of the literature and management of the patient. XL: critically revised the manuscript at all stages of its production, final approval of manuscript, review of the literature and management of the patient.

Funding This work was supported by the following: National Natural Science Foundation of China (81370787), Jiangsu Provincial Special Program of Medical Science (SBL2014030237), Key Laboratory of Children Kidney Pathology in Suzhou (SZS201511).

\section{Compliance with ethical standards}

Conflict of interest The authors declare that they have no competing interests.

Ethical standards The study complies with the Declaration of Helsinki and was approved by the Ethics Committee of our hospital.

Informed consent Informed consent was obtained from our patient and her parents.

Open Access This article is distributed under the terms of the Creative Commons Attribution 4.0 International License (http://creativeco mmons.org/licenses/by/4.0/), which permits unrestricted use, distribution, and reproduction in any medium, provided you give appropriate credit to the original author(s) and the source, provide a link to the Creative Commons license, and indicate if changes were made.

\section{References}

1. Richer O, Ulinski T, Lemelle I, Ranchin B, Loirat C, Piette JC et al (2007) Abdominal manifestations in childhood-onset systemic lupus erythematosus. Ann Rheum Dis 66(2):174-178

2. Yang Y, Ye Y, Liang L, Wu T, Zhan Z, Yang X, Xu H (2012) Systemic-lupus-erythematosus-related acute pancreatitis: a cohort from South China. Clin Dev Immunol 1:568564

3. Campos LMA, Omori CH, Lotito APN, Jesus AA, Porta G, Silva CAA (2010) Acute pancreatitis in juvenile systemic lupus erythematosus: a manifestation of macrophage activation syndrome? Lupus 19(14):1654-1658

4. Rupprecht T, Wenzel D, Michalk D (1988) Acute recurrent pancreatitis as the main symptom of lupus erythematosus disseminatus in childhood. Monatsschrift Kinderheilkunde 136(3):143-145

5. Montes de Oca MA, Babron MC, Bletry O, Broyer M, Courtecuisse V, Fontaine JL et al (1991) Thrombosis in systemic lupus erythematosus: a French collaborative study. Arch Dis Child 66(6):713-717

6. Garciaconsuegra J, Merino R, Alonso A, Goded F (1992) Systemic lupus erythematosus: a case report with unusual manifestations and favourable outcome after plasmapheresis. Eur J Pediatr 151(8):581-582

7. Huang JL, Huang CC, Chen CY, Hung IJ (1994) Acute pancreatitis: an early manifestation of systemic lupus erythematosus. Pediatr Emerg Care 10(5):291-293

8. Kolk A, Horneff G, Wilgenbus KK, Wahn V, Gerharz CD (1995) Acute lethal necrotising pancreatitis in childhood systemic lupus erythematosus - possible toxicity of immunosuppressive therapy. Clin Exp Rheumatol 13(3):399-403

9. Al-Mayouf SM, Majeed M, Al-Mehaidib A, Alsuhaibani H (2002) Pancreatic pseudocyst in paediatric systemic lupus erythematosus. Clin Rheumatol 21(3):264-266

10. Ramanan AV, Thimmarayappa AD, Baildam EM (2002) Acute lethal pancreatitis in childhood systemic lupus erythematosus. Rheumatology 41(4):467-469

11. Penalva JC, Martínez J, Pascual E, Palanca VM, Lluis F, Peiro F et al (2003) Chronic pancreatitis associated with systemic lupus erythematosus in a young girl. Pancreas 27(3):275-277

12. Fan HC, Cheng SN, Hua YM, Chu CH, Juan CJ, Lee MY et al (2003) Systemic lupus erythematosus-related acute pancreatitis: a case report. J Microbiol Immunol Infect 36(3):212-214

13. Cosentini A, Stranieri G, Capillo S, Notarangelo L, Madonna L, Lannini S et al (2005) Acute pancreatitis in the paediatric age group: a personal experience. Eur Rev Med Pharmacol Sci 9(1):33-40

14. Perrin L, Giurgea I, Valérie Baudet-Bonneville, Deschenes G, Bensman A, Ulinski T (2006) Acute pancreatitis in paediatric systemic lupus erythematosus. Acta Paediatr 95(1):121-124

15. Rose W, Puliyel MM, Moses PD, Danda D (2009) Acute pancreatitis as the initial presentation in systemic lupus erythematosus. Indian J Pediatr 76(8):846-847

16. Tominaga $\mathrm{N}$, Takahira $\mathrm{S}$, Taguchi $\mathrm{T}$, Imagawa $\mathrm{T}$, Yokota $\mathrm{S}$, Moriuchi H (2010) Acute pancreatitis associated with systemic lupus erythematosus: successful treatment with plasmapheresis followed by aggressive immunosuppressive therapy. Pediatr Int 50(1):109-111

17. Al-Musawi ZS, Nabar UJ (2011) Successful treatment of recurrent pancreatitis secondary to systemic lupus erythematosus with B-cell depletion therapy. Arch of Iran Med 14(1):66-70

18. Limwattana S, Dissaneewate P, Kritsaneepaiboon S, Dendumrongsup T, Vachvanichsanong P (2013) Systemic lupus erythematosusrelated pancreatitis in children. Clin Rheumatol 32(6):913-918

19. Gormezano NW, Otsuzi CI, Barros DL, da Silva MA, Pereira RM, Campos LM et al (2016) Macrophage activation syndrome: a severe and frequent manifestation of acute pancreatitis in 362 childhood-onset compared to 1830 adult-onset systemic lupus erythematosus patients. Semin Arthritis Rheum 45(6):706-710

20. Marques VL, Gormezano NW, Bonfá E, Aikawa NE, Terreri MT, Pereira RM et al (2016) Pancreatitis subtypes survey in 852 childhood-onset systemic lupus erythematosus patients. J Pediatr Gastroenterol Nutr 62(2):328-334

21. Basturk A, Artan R, Yilmaz A, Senol U (2016) A paediatric systemic lupus erythematosus patient presenting with acute pancreatitis: a rare case. Gastroenterol Rev 11(4):296-298

22. Marija S, Ivana B, Nina R, Dragan N, Zlatko B, Branislav J et al (2017) Toxic epidermal necrolysis in a child with lupus-associated pancreatitis. Rheumatol Int 37(7):1221-1226

23. Manjusha ML, Aditya N (2017) Acute pancreatitis in a patient with systemic lupus erythematosus. Int J Curr Res 9(9):57126-57129

24. Parasher V, Dadhich G, Khatri R, Jhanwar P (2018) Acute pancreatitis: a rare presentation of systemic lupus erythematous (SLE) in paediatric age group. Pediatr Rev 5(1):43-45

25. Jiang GM, Hu P, Wu Y (2018) Simultaneous pancreatitis and myocarditis in childhood-onset systemic lupus erythematous. Arch Rheumatol 33(x):i-iii

26. Qadiry RE, Bourrahouat A, Aitsab I, Sbihi M, Mouaffak Y, Moussair FZ et al (2018) Systemic lupus erythematosus-related pancreatitis in children: severe and lethal form. Case Rep Pediatr. https://doi.org/10.1155/2018/4612754

27. Loulouga BLPC, Bentahila A, Chkirate B (2018) Systemic lupus erythematosus complicated by macrophage activation syndrome and pancreatitis. J Orthop Res Therapy 6:JORT-1103 
28. Aanchal S, Jingwen L, Ruochen C et al (2018) Acute recurrent pancreatitis: an uncommon manifestation of systemic lupus erythematosus in children. Sci Lett 6(2):77-80

29. Weber TR, Keller MS (2001) Operative management of chronic pancreatitis in children. Arch Surg 136(5):550

30. Faller G, Thomson PD, Kala UK, Hahn D (2005) Demographics and presenting clinical features of childhood systemic lupus erythematosus. S Afr Med J 10(2):64-68

31. Bader-Meunier B, Armengaud JB, Haddad E, Salomon R, Deschenes G, Kone-Paut L et al (2005) Initial presentation of childhood-onset systemic lupus erythematosus: a French multicenter study. J Pediatr 146(5):648-653

32. Supavekin S, Chatchomchuan W, Pattaragarn A, Suntornpoch V, Sumboonnanonda A (2005) Pediatric systemic lupus erythematosus in Siriraj Hospital. J Med Assoc Thai 88(Suppl 8):S115-S123

33. Nicolino R, Angelo R, Ruben C, Graciela E, Seza O, Oscar P et al (2005) The Pediatric Rheumatology International Trials Organization criteria for the evaluation of response to therapy in juvenile systemic lupus erythematosus. Arthritis Rheum 52(9):2854-2864

34. Nydegger A, Heine RG, Ranuh R, Gegati-Levy R, Crameri J, Oliver MR (2007) Changing incidence of acute pancreatitis: 10-year experience at the Royal Children's Hospital, Melbourne. J Gastroenterol Hepatol 22(8):1313-1316

35. Park A, Latif SU, Shah AU, Tian J, Werlin S, Hsiao A et al (2009) Changing referral trends of acute pancreatitis in children: a 12-year single-center analysis. J Pediatr Gastroenterol Nutr 49(3):316-322

36. Chang YJ, Chao HC, Kong MS, Hsia SH, Lai MW, Yan DC (2011) Acute pancreatitis in children. Acta Padiatr 100(5):740-744

37. Tu YL, Yeh KW, Chen LC, Yao TC, Ou LS, Lee WI et al (2011) Differences in disease features between childhood-onset and adultonset systemic lupus erythematosus patients presenting with acute abdominal pain. Semin Arthritis Rheum 40(5):447-454

38. Frankovich J, Longhurst CA, Sutherland SM (2011) Evidencebased medicine in the EMR era. N Engl J Med 365(19):1758-1759

39. Restrepo R, Hagerott HE, Kulkarni S, Yasrebi M, Lee EY (2016) Acute pancreatitis in pediatric patients: demographics, etiology, and diagnostic imaging. AJR Am J Roentgenol 206(3):632-644

40. Chiche L, Jourde-Chiche N, Bader-Meunier B, Retornaz F, Malaekah S, Eb M et al (2016) Acute pancreatitis as a cause of mortality in pediatric systemic lupus erythematosus: results of a multiple cause-of-death analysis in France. Semin Arthritis Rheum 46(1):e6-e7

41. Wang CH, Yao TC, Huang YL, Ou LS, Yeh KW, Huang JL (2011) Acute pancreatitis in pediatric and adult-onset systemic lupus erythematosus: a comparison and review of the literature. Lupus 20(5):443-452

42. Tian XP, Zhang X (2010) Gastrointestinal involvement in systemic lupus erythematosus: insight into pathogenesis, diagnosis and treatment. World J Gastroenterol 16(24):2971-2977

43. Gerstein M, Sukhdeo S, Levy DM, Feldman BM, Benseler SM, Lawrence WKN et al (2014) A15: predicting macrophage activation syndrome in pediatric systemic lupus erythematosus patients at diagnosis. Arthritis Rheum 66:S25-S25

44. Sultan SM, Ioannou Y, Isenberg DA (1999) A review of gastrointestinal manifestation of systemic lupus erythematosus. Rheumatology 38(10):917-932

45. Sadr-Azodi O, Mattsson F, Bexlius TS, Lindblad M, Lagergren J, Ljung R (2013) Association of Oral Glucocorticoid Use With an Increased Risk of Acute Pancreatitis: a population-based nested case-control study. JAMA Intern Med 173(6):444-449

46. Nango D, Nakashima H, Hirose Y, Shiina M, Echizen H (2018) Causal relationship between acute pancreatitis and methylprednisolone pulse therapy for fulminant autoimmune hepatitis: a case report and review of literature. J Pharm Health Care Sci 4:14

47. Stummvoll G, Aringer M, Smolen J, Schmaldienst S, Jimenez-Boj $\mathrm{E}$, Horl W et al (2005) IgG immunoadsorption reduces systemic lupus erythematosus activity and proteinuria: a long term observational study. Ann Rheum Dis 64(7):1015-1021

48. Biesenbach P, Schmaldienst S, Smolen JS, Horl WH, Derfler K, Stummvoll GH (2009) Immunoadsorption in SLE: three different high affinity columns are adequately effective in removing autoantibodies and controlling disease activity. Atheroscler Suppl 10(5):114-121

Publisher's Note Springer Nature remains neutral with regard to jurisdictional claims in published maps and institutional affiliations. 